\title{
Value Relevance Of Voluntary Human Capital Disclosure: European Evidence
}

\author{
Mohamed A. Elbannan, Minnesota State University, USA
}

Omar Farooq, ADA University, Azerbaijan

\begin{abstract}
This study examines the value relevance of voluntary human capital disclosure (VHCD) in 32 European markets during the period between 1997 and 2012. VHCD allows capital market participants to evaluate the intellectual capital of disclosing firms by allowing them to assess the competitiveness of firm's human resource strategy and the productivity of workforce vis-à-vis the benchmark. The results provide strong evidence suggesting that market participants consider VHCD to be value relevant and incorporate changes in labor cost information into their pricing decisions.
\end{abstract}

Keywords: Human Capital Accounting; Voluntary Disclosure; Value Relevance

\section{INTRODUCTION}

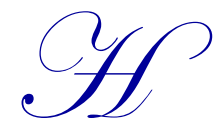

uman capital accounting is defined as the process of identifying and measuring the data about human capital and communicating this information to interested parties. Lev and Schwartz (1971) argue that, while accountants do not consider human capital as an earning asset, it can be treated at par with other forms of earning assets because it helps generate long-term benefits. This paper argues that human capital disclosure allows capital market participants to evaluate the intellectual capital of firms. The growth opportunities available to a firm are partially dependent on how much intellectual capital (and human resources are at the center of this capital) the firm possesses. We argue that providing information on firm's human capital enables market participants to assess the competitiveness of firm's human resource strategy and productivity of its workforce vis-à-vis benchmark performance. Human capital disclosure is, therefore, value relevant. Consistent with our arguments, a number of studies show that voluntary disclosure of human capital (VHCD) is valuable. Bell et al. (2002), for example, find that employee stock option-related costs are value relevant. In another study, Abdel-Khalik (2003) finds that information on the managerial skills of executives is value relevant. Lajili and Zeghal (2005) study the value relevance of VHCD provided by the U.S. firms and come to the same conclusion by documenting that these disclosures are value relevant, but Lajili and Zeghal (2006) conclude that sometimes investors fail to take advantage of the opportunities arising from the signaling indicators provided by the human capital-based information. Higher VHCD provides users of financial information with private information that can reduce information asymmetry between preparers and users of financial information and help users make more accurate assessments of the firm's potential for generating future cash flows (Leuz and Verrecchia, 2000; Bukh, 2003). These disclosures can inform users about the relative weight of firm's labor expenditures in relation to revenues and other costs and appropriateness of these expenditures in the context of firm's industry and competitive strategy. Essentially, this information can trigger market disciplinary action that can improve resource allocation and reduce agency and transaction costs.

The current paper extends above studies by documenting the value relevance of VHCD in 32 European markets during the period between 1997 and 2012. In order to conduct our investigation, we generate a sample of 28427 firm-year observations and use the panel regression with fixed effects to examine the value relevance of VHCD. Following prior literature, we estimate the value relevance of VHCD by documenting the impact of labor costs (proxy for VHCD) on prices and returns (Hassel et al., 2005; Lapointe-Antunes et al., 2006). Our results show that labor costs are significantly related to prices and returns during our sample period. Our results are robust across common and civil law countries. Our results indicate that market participants consider VHCD to be value relevant and incorporate changes in labor costs into their pricing decisions. Consistent with earlier literature, we argue that VHCD provides market participants with information that can reduce information asymmetry between insiders and outsiders. 
Therefore, markets reward firms that have high VHCD with high returns and prices. Our results initiate an argument on whether human capital disclosures should move from the voluntary to the mandatory reporting domain. While value relevance is not specifically considered by accounting regulators (Barth et al., 2001), the results in this paper may be of interest to those regulators on the issue of requiring firms to disclose detailed labor cost information in separate income statement line item(s).

The remainder of the paper is structured as follows: Section 2 summarizes the data. Section 3 presents assessment of our arguments. Section 4 document robustness of our analysis and the paper concludes with Section 5.

\section{DATA}

This paper uses the data from 32 European countries to document the value relevance of VHCD during the period between 1997 and 2012. For the purpose of this paper, we use the firms headquartered in Austria, Belgium, British Virgin Islands, Croatia, Cyprus, Czech Republic, Denmark, Estonia, Finland, France, Germany, Gibraltar, Greece, Hungary, Iceland, Ireland, Italy, Latvia, Lithuania, Luxembourg, Malta, Monaco, Netherlands, Norway, Poland, Portugal, Slovakia, Slovenia, Spain, Sweden, Switzerland, and the United Kingdom. All data is in Euros. Following sub-sections explain the data in detail.

\subsection{Outcome Variables}

This paper uses PRC and RET to measure the value relevance of VHCD. PRC is the logarithm of firm's closing stock price 4 months after the end of fiscal year, while RET is the annual return on firm's stocks measured 4 months after the end of fiscal year. The data for these variables is obtained from Compustat Global Security Daily file.

\subsection{Voluntary Human Capital Disclosure}

This paper defines uses log of total labor costs (XLR) as a proxy for voluntary human capital disclosure. The authoritative IFRS guidance on reporting of labor costs comes in the form of IFRS 2 and IAS 19 that require firms to disclose their expenditures on salaries, wages, employee benefits and executive compensation. These costs are expensed (not capitalized) and are not required to be reported as separate line item in the income statements. Firms that disclose labor costs as line items (and/or provide footnote details) tend to do so voluntarily (Ballester et al., 2002; Wyatt and Frick, 2010). Therefore, with regard to VHCD, we believe that labor costs reported as a separate line item is a good proxy for voluntary disclosures because it potentially represents the extent of a firm's commitment to higher transparency.

\subsection{Control Variables}

This paper uses the following explanatory variables in the analysis. The data for these variables is obtained from Compustat Global Fundamentals Annual file and I/B/E/S.

SIZE: We define SIZE as log of book value of assets.

LEV: We compute LEV as the ratio of total liabilities to total assets.

SGRO: This paper defines SGRO as sales growth.

LOSS: LOSS indicates the incidence of loss. It is coded as 1 if income before extraordinary income is negative and 0 otherwise.

ACOV: ACOV is analyst coverage, computed as the sum of the number of analyst recommendations issued to a firm during the year.

Table 1 documents the descriptive statistics for variables used in this analysis. The results show vast amount of heterogeneity not only among firms in different countries. Table 1 reports vast amount of variation in different variables across countries. 
Table 1. Descriptive statistics

\begin{tabular}{|c|c|c|c|c|c|c|}
\hline Country & XLR & SIZE & LEV & SGRO & LOSS & ACOV \\
\hline Austria & 2.16 & 2.53 & 0.82 & 0.08 & 5.51 & 1.10 \\
\hline Belgium & 1.53 & 2.51 & 0.79 & 0.75 & 9.60 & 2.24 \\
\hline British Virgin Islands & -3.84 & 2.05 & 0.33 & 1.15 & 39.05 & 0.00 \\
\hline Croatia & 4.39 & 3.30 & 0.89 & 0.63 & 10.32 & 3.23 \\
\hline Cyprus & -2.68 & 1.95 & 0.79 & 0.09 & 19.75 & 1.85 \\
\hline Czech Republic & 3.00 & 3.79 & 0.76 & 0.32 & 16.13 & 0.00 \\
\hline Denmark & 3.03 & 2.74 & 0.86 & 0.23 & 14.19 & 3.99 \\
\hline Estonia & 0.29 & 2.64 & 0.77 & 0.57 & 4.76 & 0.00 \\
\hline Finland & 0.41 & 2.28 & 0.88 & 0.20 & 5.14 & 8.16 \\
\hline France & 1.91 & 2.31 & 0.85 & 0.19 & 6.46 & 1.64 \\
\hline Germany & 1.26 & 2.17 & 0.74 & 0.29 & 10.63 & 0.60 \\
\hline Gibraltar & -2.55 & 1.55 & 0.88 & 0.30 & 0.00 & 0.00 \\
\hline Greece & -0.90 & 2.33 & 0.87 & 0.05 & 16.24 & 0.33 \\
\hline Hungary & 6.31 & 4.71 & 0.90 & 0.13 & 8.73 & 0.00 \\
\hline Iceland & -0.27 & 3.44 & 0.93 & 0.08 & 10.00 & 0.00 \\
\hline Ireland & -2.20 & 2.30 & 0.71 & 0.41 & 28.39 & 4.02 \\
\hline Italy & 0.37 & 3.03 & 0.91 & 1.60 & 11.63 & 1.00 \\
\hline Latvia & -0.77 & 1.13 & 0.60 & 0.25 & 13.10 & 0.00 \\
\hline Lithuania & -0.79 & 2.46 & 0.83 & 0.28 & 10.08 & 0.00 \\
\hline Luxembourg & 0.22 & 3.05 & 0.66 & 0.35 & 14.85 & 11.88 \\
\hline Malta & -2.03 & 1.83 & 0.79 & 0.27 & 3.85 & 0.00 \\
\hline Monaco & 2.04 & 2.81 & 0.80 & 0.03 & 12.50 & 0.00 \\
\hline Netherlands & 1.09 & 2.54 & 0.33 & 0.35 & 9.16 & 11.07 \\
\hline Norway & 0.20 & 2.91 & 0.54 & 1.12 & 30.02 & 6.29 \\
\hline Poland & 0.30 & 2.29 & 0.76 & 1.58 & 13.27 & 0.33 \\
\hline Portugal & 0.47 & 3.02 & 0.94 & -0.01 & 8.15 & 3.26 \\
\hline Slovakia & 1.19 & 2.32 & 0.82 & 0.32 & 21.43 & 0.00 \\
\hline Slovenia & 2.83 & 2.65 & 0.86 & -0.04 & 14.71 & 0.00 \\
\hline Spain & 1.51 & 3.38 & 0.91 & -0.03 & 4.56 & 3.25 \\
\hline Sweden & 0.96 & 2.53 & 0.80 & 0.59 & 22.89 & 3.81 \\
\hline Switzerland & 3.03 & 2.73 & 0.85 & 0.28 & 7.52 & 6.67 \\
\hline United Kingdom & -2.04 & 1.81 & 0.46 & 1.24 & 24.28 & 2.87 \\
\hline
\end{tabular}

Table 2 reports the Pearson correlation coefficients between the explanatory variables. XLR is found to be significantly related to some of the variables, particularly SIZE, LEV, and LOSS. The large correlations are expected since labor costs are bound to be affected by resources available to the firms. Such resources increase as firms become larger, have more access to debt financing, and less vulnerable to financial losses. However, the results of unreported multicollinearity tests do not show serious problems that indicate violations of regression assumptions.

Table 2. Correlation matrix

\begin{tabular}{l|c|c|c|c|c|c}
\hline \multicolumn{1}{c|}{ Variable } & XLR & SIZE & LEV & SGRO & LOSS & ACOV \\
\hline XLR & 1.0000 & & & & & \\
\hline SIZE & $0.4653 * * *$ & 1.0000 & & & \\
\hline LEV & $0.3309 * * *$ & $0.5721^{* * *}$ & 1.0000 & & & \\
\hline SGRO & -0.0100 & $0.0579 * * *$ & $-0.0334 * * *$ & 1.0000 & & \\
\hline LOSS & $-0.3497 * * *$ & $-0.2354 * * *$ & $0.0990^{* * *}$ & $-0.1155^{* * *}$ & 1.0000 & \\
\hline ACOV & $0.0147 * *$ & $0.1407 * * *$ & $0.0790 * * *$ & 0.0068 & $-0.0342 * * *$ & 1.0000 \\
\hline
\end{tabular}

Note: ${ }^{* * *},{ }^{* *},{ }^{*}$ indicates significance at the $0.01,0.05$, and 0.10 level, respectively.

\section{MODEL SPECIFICATION AND RESULTS}

Prior studies examine the value relevance of voluntary disclosures, that is, the degree of correspondence between reported information and market-based indicators (Beaver, 2002; Ettredge et al, 2005). Many of these studies use the 
Ohlson (1995) residual income valuation model or a variant thereof to examine this correspondence (Beaver, 2002). Consistent with lierature, we estimate the following panel regression equations with fixed effects. All variables are as defined above. For the purpose of completeness, we also introduce year dummies (YD) in regression equations. The coefficients of XLR measure the value relevance of VHCD. The choice of value relevance models (price or return models) follows from the prior literature (Hamberg and Beisland, 2014; Armstrong et al., 2010). Price models show the value relevance effects of labor costs, while return models show whether firms conducting changes in labor costs experience changes in value during the time period when labor cost changes are disclosed.

$$
\begin{aligned}
& \mathrm{PRC}=\alpha+\beta_{1}(\mathrm{XLR})+\beta_{2}(\mathrm{SIZE})+\beta_{3}(\mathrm{LEV})+\beta_{4}(\mathrm{SGRO}) \\
& +\beta_{5}(\mathrm{LOSS})+\beta_{6}(\mathrm{ACOV})+\sum_{\mathrm{Yr}=1998}^{2012} \beta_{\mathrm{Yr}}(\mathrm{YD})+\varepsilon
\end{aligned}
$$

and

$$
\begin{aligned}
& \mathrm{RET}=\alpha+\beta_{1}(\mathrm{XLR})+\beta_{2}(\mathrm{SIZE})+\beta_{3}(\mathrm{LEV})+\beta_{4}(\mathrm{SGRO}) \\
& +\beta_{5}(\mathrm{LOSS})+\beta_{6}(\mathrm{ACOV})+\sum_{\mathrm{Yr}=1998}^{2012} \beta_{\mathrm{Yr}}(\mathrm{YD})+\varepsilon
\end{aligned}
$$

Table 3 reports the results of our analysis. Model statistics indicate that the model is well fitted to the data with significant F-values for both equations. Our results indicate strong evidence regarding value relevance of XLR. We report significant coefficient of XLR for both equations. It indicates that VHCD is not only value relevant for price levels but also for returns. We argue that market participants extract significant information about firm's future prospects from human capital disclosure. As a result, information asymmetries between insiders and outsiders go down, thereby improving firm value. As for the control variables, the variables with significant coefficient estimates (SIZE and LOSS) possess the expected sign in all model variations, while the remaining variables (LEV, SGRO, and ACOV) are mostly non-significant. The reason for the lack of significance is potentially due to the size factor, which

\begin{tabular}{|c|c|c|c|}
\hline Variables & Expected Sign & Price & Return \\
\hline XLR & + & $0.2305 * * *$ & $0.0297 * * *$ \\
\hline SIZE & + & $1.0583 * * *$ & $-0.0841 * * *$ \\
\hline LEV & - & -0.0001 & -0.0003 \\
\hline SGRO & + & 0.0005 & 0.0005 \\
\hline LOSS & - & $-0.2398 * * *$ & $-0.2680 * * *$ \\
\hline $\mathrm{ACOV}$ & + & 0.0238 & -0.0547 \\
\hline Fixed Effects & & Yes & Yes \\
\hline No. of Observations & & 19644 & 18541 \\
\hline No. of Firms & & 5509 & 5259 \\
\hline F-Value & & $203.01 * * *$ & $106.72 * * *$ \\
\hline
\end{tabular}
has a strongly significant relation to stock price, capturing the same dynamics represented by leverage and analyst overage (debt holder market discipline and oversight) and sales growth (growth opportunities).

Table 3. Value relevance of labor costs

Note: $* * *, * *, *$ indicates significance at the $0.01,0.05$, and 0.10 level, respectively.

\section{ROBUSTNESS CHECK}

The legal systems prevailing in the Europe are diverse but are typically classified as common and civil law countries. The differences in the legal infrastructure due to this classification have significant implications for economic choices in these nations. We believe that the analysis conducted in this study cannot be complete without examining the same research questions separately for common and civil law countries. Common law countries typically involve more dependence on equity financing, more fragmented ownership base, and more active stock markets compared to civil aw countries. Accordingly, we re-estimate the analysis after partitioning the sample into common and civil law groups. 
The results are shown in Tables 4 . The results show that our results hold in both legal regimes. We report significant coefficient for XLR in both legal regimes for both equations. Interestingly, we show that VHCD is more value relevant in civil law countries. We report higher coefficient of XLR in civil law countries.

Table 4. Value relevance of labor costs in different legal regimes

\begin{tabular}{|c|c|c|c|c|c|}
\hline \multirow[b]{2}{*}{ Variables } & \multirow[b]{2}{*}{$\begin{array}{c}\text { Expected } \\
\text { Sign }\end{array}$} & \multicolumn{2}{|c|}{ Common Law Countries } & \multicolumn{2}{|c|}{ Civil Law Countries } \\
\hline & & Price & Return & Price & Return \\
\hline XLR & + & $0.2032 * * *$ & $0.0253^{* *}$ & $0.2498 * * *$ & $0.0435 * * *$ \\
\hline SIZE & + & $1.0228 * * *$ & -0.0038 & $0.8951 * * *$ & $-0.1070 * *$ \\
\hline LEV & - & $-0.0002 * *$ & $-0.0007 * * *$ & -0.0001 & 0.0001 \\
\hline SGRO & + & $0.0006^{* *}$ & 0.0002 & 0.0004 & 0.0006 \\
\hline LOSS & - & $-0.2134 * * *$ & $-0.2386^{* * *}$ & $-0.2857 * * *$ & $-0.2926 * * *$ \\
\hline ACOV & + & 0.0229 & -0.0550 & -0.0165 & -0.0208 \\
\hline Fixed Effects & & Yes & Yes & Yes & Yes \\
\hline No. of Observations & & 7653 & 7199 & 11991 & 11342 \\
\hline No. of Firms & & 1853 & 1792 & 3656 & 3467 \\
\hline F-Value & & $59.29 * * *$ & $38.34 * * *$ & $204.02 * * *$ & $89.53 * * *$ \\
\hline
\end{tabular}

Note: $* * * * *, *$ indicates significance at the $0.01,0.05$, and 0.10 level, respectively.

\section{CONCLUSION}

This study examines the value relevance of voluntary human capital disclosures in Europe during the period between 1997 and 2012. We document whether VHCD are value relevant by running a regression of stock prices and returns (separately) on labor costs and a vector of control variables. We proxy for VHCD with labor costs reported by firms and assess value relevance by using price and returns as dependent variables. Measuring value relevance using returns serves to determine whether price changes correspond to changes in the variable of interest (labor costs). The results provide strong evidence suggesting that market participants consider VHCD to be value relevant and incorporate changes in labor cost information into their pricing decisions. Since ours is a cross-country sample that is comprised of civil and common law countries, we repeat the analysis for each group of countries separately. We find that labor costs (and their changes) are value relevant for firms headquartered in both legal regimes. It should be noted that one limitation to this study relates to the choice and measurement of model variables. The study models incorporate labor costs in total, book value of assets, total liabilities scaled by total assets, sales growth, loss, and analyst recommendations. While many of these variables are commonly used in the literature, correlated omitted variables could account for the relations under investigation. To the best of our knowledge, this is the first study on the value relevance of VHCD in a cross-country setting. It remains for future research to be conducted in individual countries to see how these results hold. Furthermore, several studies reveal that the purpose of providing VHCD is due to seeking legitimacy or managing relations with powerful resource providers (Abeysekera, 2008). Therefore, future research examining whether mandatorily requiring human capital disclosures as income statement line item or footnote disclosure helps firms earn legitimacy and helps market participants assess the appropriateness of firm human capital practices.

\section{AUTHOR BIOGRAPHY}

Mohamed A. Elbannan is a faculty member at Minnesota State University, USA. His area of research is financial accounting and corporate governance.

Omar Farooq is working is a faculty member at ADA University, Azerbaijan. His area of research is corporate governance in emerging markets. 


\section{REFERENCES}

Abdel-khalik, A.R., (2003). Self-sorting, incentive compensation and human-capital assets. European Accounting Review, 12(4), 661-697.

Abeysekera, I., (2008). Motivations behind human capital disclosure in annual reports, Accounting Forum, 32(1), 16-29.

Armstrong, C.S., Barth, M.E., Jagolinzer, A.D., and Riedl, E.J., (2010). Market reaction to the adoption of IFRS in Europe. The Accounting Review, 85(1), pp. 31-61.

Ballester, M., Livnat, J., and Sinha, N., (2002). Labor costs and investments in human capital. Journal of Accounting, Auditing and Finance, 17(4), pp. 351-373.

Barth, M.E., Beaver, W.H., and Landsman, W.R., (2001). The relevance of the value relevance literature for financial accounting standard setting: Another view. Journal of Accounting \& Economics, 31(1), pp. 77-104.

Beaver, W., (2002). Perspectives in recent capital markets research. The Accounting Review, 77(2), pp. 453-474.

Bell, T.B., Landsman, W.R., Miller, B.L., and Yeh, S., (2002). The valuation implications of employee stock option accounting for profitable computer software firms. The Accounting Review, 77(4), pp. 971-996.

Bukh, P., (2003). The relevance of intellectual capital disclosure: a paradox? Accounting, Auditing \& Accountability Journal, 16(1), pp. 49-56.

Ettredge, M.L., Soo, Y.K., Smith, D.B., and Zarowin, P.A., (2005). The impact of SFAS No. 131 business segment data on the market's ability to anticipate future earnings, The Accounting Review, 80(3), pp. 773-804.

Hamberg, M. and Beisland, L.A., (2014). Changes in the value relevance of goodwill accounting following the adoption of IFRS 3. Journal of International Accounting, Auditing and Taxation, 23(2), pp. 59-73.

Hassel, L., Nilsson, H., and Nyquist, S., (2005). The value relevance of environmental performance. European Accounting Review. 14(1), pp. 41-61.

Lajili, K. and Zeghal, D., (2005), Labor cost voluntary disclosures and firm equity values: Is human capital information valuerelevant? International Journal of Accounting, Auditing \& Taxation, 14(2), pp. 121-138.

Lapointe-Antunes, P., Cormier, D., Magnan, M., and Gay-Angers, S., (2006). On the relationship between voluntary disclosure, earnings, smoothing and value-relevance of earnings: The case of Switzerland. European Accounting Review, 15(4), pp. 465-505.

Leuz, C. and Verrecchia, R.E., (2000). The economic consequences of increased disclosure. Journal of Accounting Research, 38, pp. 91-124.

Lev, B. and Schwartz, A. (1971). On the use of the economic concepts of human capital in financial statements, The Accounting Review, 46(1), pp. 103-112.

Ohlson, J., (1995). Earnings, book values and dividends in security valuation, Contemporary Accounting Research. 11(2), pp. 661-687.

Wyatt, A. and Frick, H., (2010). Accounting for investments in human capital: A review. Australian Accounting Review, 20(3), pp. 199-220. 